\title{
Optimization Studies on Subcritical Water Extraction of Fuels and Fine Chemicals from Prosopis juliflora: An Invasive Weed Tree
}

\author{
Chitra Devi Venkatachalam", Mothil Sengottian1, Sathish Raam Ravichandran, \\ Kirankumar Subramaniyan², Parthiban Kalappan Thangamuthu ${ }^{3}$ \\ 1 Department of Chemical Engineering, Kongu Engineering College, 638060 Erode, Tamil Nadu, India
2 Process Engineering Group, Southern Petrochemical Industries Corporation Ltd, 628005 Tuticorin, Tamil Nadu, India
${ }^{3}$ Department of Agroforestry, Forest College and Research Institute, 641301 Mettupalayam, Tamil Nadu, India
${ }^{*}$ Corresponding author, e-mail: chitrasuresh@kongu.ac.in
}

Received: 26 October 2019, Accepted: 19 February 2020, Published online: 09 July 2020

\begin{abstract}
Waste lignocellulosic biomass obtained from the dry plant matter is the most abundantly available resource for the production of biofuels, and biochar. The invasive weed tree of Prosopis juliflora was employed as feedstock for the extraction process, which converts biomass into biogas, bio-oil, and biochar in the presence of subcritical water at high temperatures $\left(250{ }^{\circ} \mathrm{C}\right.$ to $\left.374{ }^{\circ} \mathrm{C}\right)$ and pressures (4-22 MPa). The extraction process was performed inside a $50 \mathrm{ml}$ stainless steel hydrothermal reactor with $3.5 \mathrm{~g}$ of feedstock and varying process parameters such as temperatures $\left(250-325^{\circ} \mathrm{C}\right)$ and reaction time $(30-120 \mathrm{~min})$ and biomass to water loading (10-30 \% w/v). The response surface methodology was employed to optimize the parameters for maximizing the bio-oil yield under subcritical condition using Design Expert 8.0.7.1 software. The \% yield of bio-oil and biochar during this process were taken as responses. The biomass and bio-oil were characterized using proximate and ultimate elemental analysis, thermogravimetric analysis, and gas-chromatography mass spectroscopy. The results showed that the maximal yield of bio-oil $3.65 \%$ was obtained at a temperature of $277.62{ }^{\circ} \mathrm{C}$, reaction time $59.98 \mathrm{~min}$ and biomass to water loading $20.13 \% \mathrm{w} / \mathrm{v}$. The resulted bio-oil was found to contain long-chain alkanes, ketones, carboxylic acids, amines, and phenols.
\end{abstract}

Keywords

Prosopis juliflora, subcritical water extraction, bio-oil, biochar

\section{Introduction}

Prosopis juliflora is a shrub or small tree in the family Fabaceae. It is native to Mexico, South America and the Caribbean [1]. It grows to a height of up to $12 \mathrm{~m}$; trunk diameter of up to $1.2 \mathrm{~m}$ and deciduous, bi-pinnate, light green, compounded leaves with 12 to 20 leaflets shown in Fig. 1 (a). The flowers are in 5-10 cm long clusters of green-yellow cylindrical spikes at the ends of branches. Pods are 20 to $30 \mathrm{~cm}$ long and contain between 10-30 seeds per pod as shown in Fig. 1 (b) [2]. Prosopis juliflora wood contains $66.20 \%$ holocellulose (47.50\% $\alpha$-cellulose and $18.70 \%$ pentosans), $29.10 \%$ Klason lignin, and $2.02 \%$ ash [3]. Prosopis juliflora has a hard exterior shown in Fig. 2 (a) that can adapt to any drought conditions and has proven to be one of the best firewood with very low moisture content of $7.3 \%$ providing $4.952 \mathrm{kcal}$ energy for cooking in most households in Kenya, where over $80 \%$ of the rural and urban population use firewood for cooking and heating [4]. The ultrastructure of Prosopis juliflora collected in Petrolina, State of Pernambuco, Brazil (Figs. 2. (b)-(d)) shows that $18 \%$ of the total volume is occupied by vessels present in few radial multiples of 3-4 and in clusters, with scant diffuse apotracheal parenchyma cells upto $16 \%$, homogeneous rays $18 \%$, and the rest is constituted by libriform, non-separate, often gelatinous fibrous tissue that extremely short to short (620-1009-1228 $\mu \mathrm{m})$; narrow, 10-13-18 $\mu \mathrm{m}$ in diameter; walls very thick $(1.5-2.5-4.5 \mu \mathrm{m})$ make it a best-evolved species for arid conditions [5].

Prosopis juliflora once touted as a savior for firewood of the drought-prone areas in the southern districts of Tamil Nadu has now become a threat to the environmental system [6]. It is considered a noxious invader in several 

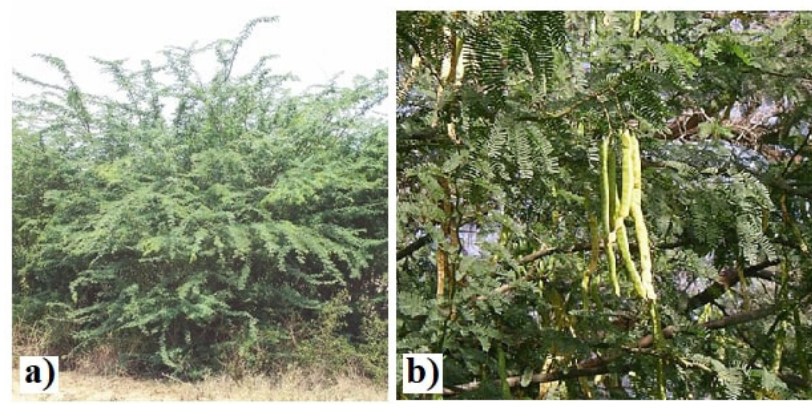

Fig. 1 Prosopis juliflora a) Tree b) Branch with seed pods
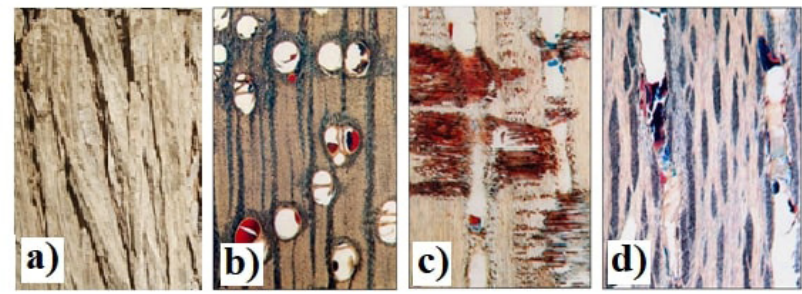

Fig. 2 Prosopis juliflora a) Bark b) Cross section at 50X c) Radial sections at 50X d) Tangential section at 50X [5]

countries like Ethiopia, Hawaii, Sri Lanka, Jamaica, Kenya, the Middle East, India, Nigeria, Sudan, Somalia, Senegal and Southern Africa [7]. A mature plant produces between one lakh to ten lakhs of seeds that remain viable for up to 10 years. These seeds are spread by cattle and other animals that consume the seed pods and spread the seeds in their droppings [8]. It is very hard and expensive to remove vast spreading plant as it can regenerate from the roots. In Australia, Prosopis juliflora (mesquite) has colonized over 800,000 hectares of arable land, had severe economic and environmental impacts [9]. It also takes over pastoral grasslands and uses scarce water. It was recorded in 1960 that live roots and fibrous tissues of Prosopis juliflora were discovered at a depth of 53 meters (175 feet) at an open-pit mine near Tucson, Arizona [10]. Livestock on the consumption of excessive amounts of seed pods are reported to be poisoned due to alkaloids causing neural damage and degeneration of nerves of the mandibular and trigeminal tissues [11]. It causes land erosion due to the loss of the grasslands that are habitats for native plants and animals. With its thorns and many low branches it forms impenetrable thickets that prevent cattle from accessing watering holes, etc. and also provides shelter for feral animals such as pigs and cats [12]. After clearing this invasive species from the arid regions of Northern Cape Province of South Africa, it is documented that $70 \mathrm{~m}^{3} / \mathrm{ha}$ of groundwater can be prevented from loss in a month [13]. This led to the idea to use invasive Prosopis juliflora plant biomass to meet the energy demand.
The rapid industrialization and day-by-day growth of energy demand resulting in depletion of non-renewable fossil fuels, and an increase in environmental pollution led to the search for alternate renewable, sustainable sources, and new technologies [14]. Biomass-derived fuels have proved to be the promising path with various routes available for its processing such as pyrolysis, trans-esterification, steam reforming, hydrothermal conversion, etc. [15-17]. Hydrothermal processing is divided into three separate processes, namely: hydrothermal carbonization (HTC), hydrothermal liquefaction (HTL) and hydrothermal gasification (HTG) depending upon the severity of their operating conditions.

Hydrothermal liquefaction otherwise called Subcritical Water Extraction (SCWE) of biomass is the thermochemical conversion of biomass into hydrocarbon fuel like products by processing it in a hot, pressurized water environment for sufficient time to break down the solid bio-polymeric structure to mainly liquid components [18]. Typical extraction conditions are $250-374{ }^{\circ} \mathrm{C}$ of temperature and operating pressures from 4 to $22 \mathrm{MPa}$ of pressure [19]. The process is meant to provide a means for treating wet materials without drying and to access ionic reaction conditions by maintaining a liquid water processing medium. SCWE has many favorable advantages that other processes lack, where it results in high yield of various chemicals like acids, alcohols, alkanes, alkenes, aldehydes, ketones, esters, ethers, phenols, and other aromatic compounds with some amount of polymeric impurities [20]. There are few studies on the conversion of the woody Prosopis juliflora biomass into bio-oil as separate and in combination with hydrocarbon wastes namely: combustion, gasification, torrefaction, microwave pyrolysis, co-thermal liquefaction, etc [21-26]. Here is an attempt made to utilize finely powdered Prosopis juliflora waste biomass as feedstock and convert it effectively and profitably into fuels and fine chemicals through subcritical water extraction. The response surface methodology is utilized to maximize the bio-oil yield during subcritical water extraction.

\section{Materials and methods}

\subsection{Materials}

Prosopis juliflora woodcutting of diameter $3.5 \mathrm{~cm}$ and length $30 \mathrm{~cm}$ was obtained from Thoppupalayam, Perundurai, Tamil Nadu, India; it was compared and identified by Dr. N. Anjanadevi, Department of Botany, Vellalar College for Women, Erode, Tamil Nadu, India. The branches and the spikes were removed from the exterior of the cutting using a blade. The size reduction of the 
wood cutting was performed using wood chipper for a size of $5.08 \mathrm{~cm} \times 5.08 \mathrm{~cm}$ with $2.54 \mathrm{~cm}$ thickness and dried in a tray drier at $80^{\circ} \mathrm{C}$ for $6 \mathrm{~h}$ using air velocity of $0.5 \mathrm{~m} / \mathrm{s}$ [27]. The dried wood chips were grounded in pulverizer for getting a homogeneous particle size $(0.5 \mathrm{~mm}$ to $1 \mathrm{~mm})$ that pass through ASTM standard \# Mesh 18 and retained in \# Mesh 35 and stored in an airtight container.

\subsection{Experimental procedure}

\subsubsection{Thermo-gravimetric analysis of feedstock}

Thermogravimetric Analysis (TGA) of the dried powdered feedstock was carried out in a Universal V4.5A Thermal Analyzer Instrument coupled to a ThermoStar Balzers quadrupole mass spectrometer. A small sample of $10 \mathrm{mg}$ was used to prevent heat and mass transfer limitations. The ion source was operated at $70 \mathrm{eV}$. The analysis was performed under the inert gas atmosphere i.e argon with a flow rate of $2 \mathrm{~L} \mathrm{~h}^{-1}$ at the heating rate $5^{\circ} \mathrm{C} \mathrm{min}^{-1}$ up to $800{ }^{\circ} \mathrm{C}$ for $30 \mathrm{~min}$. The weight of the sample and the derivative weight loss were continuously recorded along the experiment.

\subsubsection{Proximate and Ultimate analysis}

The proximate analysis (ash, volatile matter, moisture, and fixed carbon) of feedstock and biochar samples were carried out according to the TAPPI and ASTM standards. The dried sample taken in crucible without lid was ignited at $525 \pm 25{ }^{\circ} \mathrm{C}$ for $30-60 \mathrm{~min}$ in a muffle furnace to determine percentage ash (TAPPI-T211om-02) [28]. The volatile matter of samples was measured using ASTM-E872 by heating the dried sample to $950 \pm 20{ }^{\circ} \mathrm{C}$ for $7 \mathrm{~min}$ in the muffle furnace inside a covered crucible and cooled in a desiccator. The percentage of moisture was determined using TAPPI-T550om-08 by placing the measured amount of sample in the hot air oven operated at $105 \pm 2{ }^{\circ} \mathrm{C}$ for $1 \mathrm{~h}$ with free access of air [29]. Fixed Carbon Content (FCC) was estimated using Eq. (1):

$$
\operatorname{FCC}(\%)=100-(\% \text { ash }+\% \text { volatile }+\% \text { moisture }) \text {. }
$$

The elemental composition of the solid samples $(\mathrm{C}, \mathrm{H}$, and $\mathrm{N}$; O content by difference) were determined using $\mathrm{CHN}$ Elemental analyzer (Elementar Vario EL III). The theoretical Higher Heating Value (HHV) in $\mathrm{MJkg}^{-1}$ was calculated using an empirical correlation developed by Sheng and Azevedo [30]:

$$
\mathrm{HHV}=-1.3675+0.3137 \mathrm{C}+0.7009 \mathrm{H}+0.0318 \mathrm{O} \text {. }
$$

Equation (2) is used to predict the HHV, where C, H, and $\mathrm{O}$, represent the weight percentages of carbon, hydrogen, and oxygen in the sample, respectively [30].

\subsubsection{Subcritical water extraction and Box-Behnken design optimization}

The dry powdered biomass of $3.5 \mathrm{~g}$ mixed with an appropriate amount of distilled water (10-30\%w/v) was loaded into a $50 \mathrm{ml}$ stainless steel hydrothermal reactor and was sealed. The reactor was placed in a muffle furnace and heated for a predetermined time under autogenous pressure for liquefaction temperatures 250 to $325{ }^{\circ} \mathrm{C}$ with water as an auto-catalyst. After heating the reactor was removed from the furnace and quenched rapidly in a cold water bath to condense the bio-oil vapors. $30 \mathrm{~mL}$ of hexane was added to the reaction product and mixed thoroughly using a handheld electric blender. The resulting mixture was filtered using a Wattman filter paper under vacuum; both the filtrate that contains the leached out bio-oil and the residual biochar were dried in an air oven at $103 \pm 5{ }^{\circ} \mathrm{C}$ to evaporate the excess solvent. The obtained bio-oil and biochar were weighed separately and stored under refrigeration under $-2{ }^{\circ} \mathrm{C}$ for further testing. The biogas and the incondensable products from the reactor are not considered in the study. Bio-oil yield and biochar yield are calculated as given in Eq. (3):

$$
Y_{p}=\frac{m_{p}}{m_{0}-m_{w}-m_{a s h}},
$$

where $Y_{p}$ is the yield of product either bio-oil or biochar, $m_{p}$ is the mass of bio-oil or biochar, $m_{0}$ is the initial mass of raw biomass taken, $m_{w}$ and $m_{a s h}$ are the mass of moisture and ash in raw biomass respectively.

Response Surface Methodology (RSM) is a powerful tool that has been widely and successfully applied for evaluating the effect of process variables and the optimization of various bioprocesses [31]. In this study, it was used to optimize the effect of independent variables such as temperature, reaction time and biomass to water loading on bio-oil and biochar yield using subcritical water extraction. The experiments were based on $2^{3}$ factorial Box-Behnken Design (BBD) with three factors at three levels and each independent variable was coded at levels between $-1,0$ and +1 corresponding to the lowest, middle and highest level [32]. The RSM based optimization was carried out using Design Expert 8.0.7.1 software (Stat Ease Inc., Minneapolis, USA) and the BBD design for optimization of subcritical water extraction with the variables and their respective coded levels are given in Table 1. The coding of the variables was done using the Eq. (4):

$$
x_{i}=\frac{X_{i}-X_{m}}{\Delta X_{i}} \text {, }
$$


Table 1 BBD design for optimization of subcritical water extraction

\begin{tabular}{llcccc}
\hline \multirow{2}{*}{ Variables, unit } & \multicolumn{2}{c}{ Factors } & \multicolumn{3}{c}{ Levels } \\
\cline { 3 - 5 } \multicolumn{2}{l}{} & $X$ & -1 & 0 & +1 \\
\hline A & Temperature $\left({ }^{\circ} \mathrm{C}\right)$ & $X_{1}$ & 250 & 287.5 & 325 \\
B & Reaction Time $(\mathrm{min})$ & $X_{2}$ & 15 & 67.5 & 120 \\
\multirow{2}{*}{ C } & $\begin{array}{l}\text { Biomass to Water } \\
\text { Loading }(\% \mathrm{w} / \mathrm{v})\end{array}$ & $X_{3}$ & 10 & 20 & 30 \\
\hline
\end{tabular}

where $x_{i}$ is the dimensionless value of the independent variable, $X_{\mathrm{i}}$ is the real value of the independent variable, $X_{m}$ is the real value of the independent variable at the midpoint and $\Delta X_{i}$ is the step change of the real value corresponding to a variation of a unit for the dimensional value of the variable $i=1,2,3, \ldots k[33]$.

The total number of experimental runs $(N)$ for BBD was calculated using the following Eq. (5):

$N=K^{2}+K+C_{p}$,

where $K$ is number of factors and $C_{p}$ is the number of central points. For normal three levels factorial design the number of runs will be $3^{3}$ i.e. 27 . BBD eliminates the complex intermediate point responses and finally results with 17 runs with 5 central points [34].

The response surface of the bio-oil and biochar yield considering all linear, square and interaction terms using the second order polynomial equation is given by Eq. (6):

$$
\begin{aligned}
& Y=\beta_{0}+\sum_{k=1}^{q} \beta_{k} x_{k i}+\sum_{k=1}^{q} \beta_{k k} x_{k i}^{2} \\
& +\sum_{k=1}^{q-1} \sum_{l=k+1}^{q} \beta_{k l} x_{k i} x_{l i}+\varepsilon_{i},
\end{aligned}
$$

where $Y$ is the response for bio-oil yield $\left(Y_{O}\right)$ and biochar yield $\left(Y_{C}\right) ; \beta_{0}$ is the intercept coefficient; $\beta_{k}, \beta_{k k}$ and $\beta_{k l}$ are interaction coefficients of linear, quadratic and second order terms of model respectively; $x_{k i}$ and $x_{l i}$ are process variables ( $k$ and $l$ range from 1 to $q$ ); $q$ is the number of independent parameters and $\varepsilon_{i}$ is the error [35]. The final equation for three independent parameters $(q)$ with the error term is given by Eq. (7):

$$
\begin{aligned}
& Y=\beta_{0}+\beta_{1} x_{1}+\beta_{2} x_{2}+\beta_{3} x_{3}+\beta_{11} x_{1}^{2} \\
& +\beta_{22} x_{2}^{2}+\beta_{33} x_{3}^{2}+\beta_{12} x_{1} x_{2}+\beta_{13} x_{1} x_{3}+\beta_{23} x_{2} x_{3}+\varepsilon_{i} .
\end{aligned}
$$

\subsubsection{Characterization of subcritical bio-oil extract}

The bio-oil obtained during the subcritical water extraction at the optimum experimental condition was analyzed by Gas Chromatography-Mass Spectrometer (GC-MS) analysis using Agilent 7890 with an FID detector for GC and Jeol AccuTOF GCV for MS to find the constituents from $\mathrm{C} 4$ to $\mathrm{C} 20$. GC-MS was equipped with a glass column of $0.53 \mathrm{~mm}$ internal diameter, $105 \mathrm{~m}$ length, and 0.25 $\mu \mathrm{m}$ film thickness. The sample size of $2 \mu \mathrm{L}$ was injected through the injector with helium as carrier gas. The MS was taken at $70 \mathrm{eV}$ of ionization energy. The carrier gas column flow and purge flow were fixed to $1 \mathrm{~mL} \mathrm{~min}^{-1}$ and $5 \mathrm{~mL} \mathrm{~min}^{-1}$ respectively with $50{ }^{\circ} \mathrm{C}$ as the initial temperature of the oven and a ramp of $22 \mathrm{~min}$ to $280^{\circ} \mathrm{C}$ and held for $35 \mathrm{~min}$. The mass range was fixed from 45 to $300 \mathrm{amu}$, scan interval of $0.50 \mathrm{~s}, 260{ }^{\circ} \mathrm{C}$ with a split ratio of 10:0. The total running time of GC-MS was $65 \mathrm{~min}$. The relative $\%$ amount of each component was expressed as a percentage with peak area normalization.

\section{Results and discussion}

\subsection{Thermogravimetric analysis}

The thermogravimetric analysis results of feedstock under the inert gas atmosphere shows clearly that the maximum weight reduction of the biomass was between the temperatures 225 to $350{ }^{\circ} \mathrm{C}$ and thus intermediate temperatures $250-325{ }^{\circ} \mathrm{C}$ was taken for the subcritical extraction study. The TGA result of Prosopis juliflora is given in Fig. 3. The TGA analysis also revealed two proximate analysis parameters: moisture content $7.10 \%$ and volatile matter $79.59 \%$.

\subsection{Proximate and ultimate analysis}

The proximate analysis result for the feedstock is given in Table 2. This result was in accordance with the thermogravimetric analysis and the results from Oduor and Githiomi [4].

The ultimate analysis was performed on feedstock and its elemental composition under dry basis with calculated HHV value is given in Table 3 .

\subsection{Box-Behnken analysis on bio-oil and biochar yield by subcritical water extraction}

The RSM optimization of bio-oil and biochar yield obtained by subcritical water extraction was done under BBD design with three process parameters (temperature, reaction time and biomass to water loading) at three levels $(-1,0,+1)$.

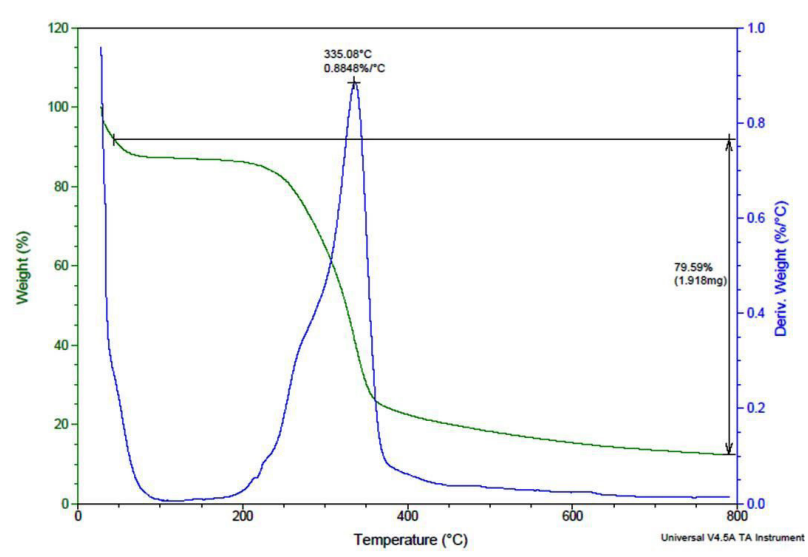

Fig. 3 Thermogravimetric analysis of raw feed- Prosopis juliflora 
Table 2 Proximate Analysis of Prosopis juliflora

\begin{tabular}{lcccc}
\hline & $\begin{array}{c}\text { Volatile } \\
\text { Matter }\end{array}$ & Ash & Moisture & $\begin{array}{c}\text { Fixed } \\
\text { Carbon }\end{array}$ \\
\hline Prosopis juliflora & 77.38 & 1.35 & 7.92 & 13.35 \\
\hline
\end{tabular}

Table 3 Ultimate analysis of Prosopis juliflora

\begin{tabular}{cccccc}
\hline & $\mathrm{C}$ & $\mathrm{H}$ & $\mathrm{N}$ & $\mathrm{O}$ & $\begin{array}{c}\mathrm{HHV} \\
\mathrm{MJ} \mathrm{kg}^{-1} \mathrm{~K}^{-1}\end{array}$ \\
\hline Prosopis juliflora & 48.2 & 6.57 & 0.31 & 44.92 & 19.78 \\
\hline
\end{tabular}

The experiments were performed for the 12 runs and 5 central points of the BBD, a totally of 17 runs rather than 27 runs in case of full factorial and results were fed to obtain a mathematical model. The predicted values were obtained by a model fitting technique using Design Expert 8.0.7.1 software and the values were shown in Table 4.

The adequacy of the model was checked by fitting the experimental data with four high degree polynomial models viz., linear, interactive (2FI), quadratic and cubic models over which sequential model sum of squares and model summary statistics tests were carried out. Model summary given in Table 5 indicated that the quadratic model was highly sufficient and suggested for the subcritical water extraction study with the $p$-value less than 0.05 , maximum $F$-value of 464.55 for bio-oil and higher sequential model sum of squares, while the cubic model was said to be aliased. While in case of biochar the maximum $F$-value is 487.67 for linear model but both the $p$-value for linear and quadratic are $<0.05$. Hence quadratic model is also suggested for model fitting.

\subsection{Fitting of second order polynomial equation and statistical analysis}

The empirical correlation between the experimental results of subcritical water extraction of bio-oil and biochar from Prosopis juliflora biomass obtained on the basis of BBD model derived from Eq. (7) and the input variables (Temperature- $\mathrm{X}_{1}$, Reaction Time- $\mathrm{X}_{2}$, Biomass to Water loading- $\mathrm{X}_{3}$ ) were expressed in terms of a second-order polynomial equation in terms of the coded factors given as Eqs. (8) and (9):

$$
\begin{aligned}
& Y_{O}=3.59-0.39 X_{1}-0.2 X_{2} \\
& -0.059 X_{3}+0.012 X_{1} X_{2}-0.24 X_{1} X_{3} \\
& -0.087 X_{2} X_{3}-0.74 X_{1}^{2}-0.72 X_{2}^{2}-0.65 X_{3}^{2}, \\
& Y_{C}=32.88-8.08 X_{1}-3.70 X_{2} \\
& -0.25 X_{3}+0.63 X_{1} X_{2}-0.13 X_{1} X_{3} \\
& -0.025 X_{2} X_{3}+0.57 X_{1}^{2}-0.028 X_{2}^{2}-0.57 X_{3}^{2} .
\end{aligned}
$$

The ANOVA results from Table 6 indicated that the model equations involving the relationship between the

Table 4 Box-Behnken experimental design matrix and its response

\begin{tabular}{lccccccc}
\hline & Run & Temperature $\left({ }^{\circ} \mathrm{C}\right)$ & Reaction Time (min) & $\begin{array}{c}\text { Biomass to Water } \\
\text { Loading }(\% \mathrm{w} / \mathrm{v})\end{array}$ & \multicolumn{2}{c}{ Bio-oil Yield (\%) } & \multicolumn{2}{c}{ Biochar Yield (\%) } \\
\hline & & & & $Y_{\text {Oexp }}$ & $Y_{\text {Opre }}$ & $Y_{\text {Cexp }}$ & $Y_{\text {Cpre }}$ \\
1 & 250 & 67.5 & 10 & 2.39 & 2.4 & 42.5 & 42.23 \\
2 & 287.5 & 120 & 10 & 2.18 & 2.17 & 30.1 & 30 \\
$3^{\mathrm{a}}$ & 287.5 & 67.5 & 20 & 3.53 & 3.59 & 33.1 & 32.88 \\
4 & 325 & 120 & 20 & 1.6 & 1.56 & 22.4 & 22.28 \\
5 & 250 & 120 & 20 & 2.3 & 2.3 & 36.8 & 37.18 \\
$6^{\mathrm{a}}$ & 287.5 & 120 & 20 & 3.58 & 3.59 & 32.9 & 32.88 \\
7 & 287.5 & 67.5 & 30 & 1.82 & 1.87 & 29.6 & 29.45 \\
$8^{\mathrm{a}}$ & 287.5 & 67.5 & 20 & 3.69 & 3.59 & 33.3 & 32.88 \\
9 & 325 & 15 & 30 & 1.52 & 1.51 & 25.3 & 25.58 \\
10 & 287.5 & 15 & 30 & 2.44 & 2.45 & 36.8 & 36.9 \\
11 & 287.5 & 15 & 10 & 2.45 & 2.4 & 37.2 & 37.35 \\
12 & 250 & 67.5 & 20 & 2.69 & 2.73 & 45.7 & 45.82 \\
13 & 250 & 67.5 & 30 & 2.82 & 2.76 & 42.2 & 41.98 \\
$14^{\mathrm{a}}$ & 287.5 & 67.5 & 20 & 3.63 & 3.59 & 32.5 & 32.88 \\
$15^{\mathrm{a}}$ & 287.5 & 15 & 20 & 3.54 & 3.59 & 32.6 & 32.88 \\
16 & 325 & 67.5 & 10 & 1.94 & 1.94 & 28.8 & 28.42 \\
17 & 325 & & 2.05 & 2.11 & 26.1 & 26.33 \\
\hline
\end{tabular}

${ }^{\mathrm{a}}$ Central points 
Table 5 Sequential model summary for subcritical water extraction Bio-oil

\begin{tabular}{lccccc}
\hline Source & $\begin{array}{c}\text { Sum of } \\
\text { squares }\end{array}$ & df & $\begin{array}{c}\text { Mean } \\
\text { square }\end{array}$ & $F$-value & $\begin{array}{c}p \text {-value } \\
\text { Prob }>\text { F }\end{array}$ \\
\hline Mean vs total & 114.76 & 1 & 114.76 & & \\
Linear vs mean & 1.5492 & 3 & 0.5164 & 0.9150 & 0.4607 \\
2FI vs linear & 0.2617 & 3 & 0.0872 & 0.1233 & 0.9442 \\
Quadratic vs 2FI & 7.0405 & 3 & 2.3468 & 464.55 & $<0.0001$ \\
Cubic vs & & & & & \\
quadratic & 0.0168 & 3 & 0.0056 & 1.2660 & 0.3986 \\
Residual & 0.0177 & 4 & 0.0044 & & \\
Total & 123.65 & 17 & 7.2735 & & \\
Biochar & & & & & \\
& Sum of & & Mean & & $p$-value \\
Source & squares & df & square & $F$-value & Prob $>$ F \\
Mean vs total & 18971 & 1 & 18971 & & \\
Linear vs mean & 631.67 & 3 & 210.56 & 486.67 & $<0.0001$ \\
2FI vs linear & 1.6275 & 3 & 0.5425 & 1.357 & 0.3111 \\
Quadratic vs 2FI & 2.9189 & 3 & 0.9730 & 6.318 & 0.0211 \\
Cubic vs & & & & & \\
quadratic & 0.63 & 3 & 0.21 & 1.875 & 0.2747 \\
Residual & 0.448 & 4 & 0.112 & & \\
Total & 19608.5 & 17 & & & \\
\hline & & & & & \\
\hline
\end{tabular}

process parameters $\left(X_{1}, X_{2}\right.$, and $\left.X_{3}\right)$ and the response $Y$ was found adequate. The significance of each parameter was evaluated using analysis of variance (ANOVA) followed by Fisher's statistical test (F-test) and $F$-value for all linear, square and interactive variables in both the second-order polynomial equations were determined. The $F$-value indicated the influence of each controlled factor on the tested model [36]. The ANOVA results for subcritical extraction process showed larger Fisher F-values of 199.29, which implied that the model was significant and there was less variation in the response. The associated $p$-values was less than 0.05 indicating the models were statistically significant and greater than 0.1 indicated the model terms were not significant [37]. The ANOVA results depicted that the model terms $X_{1}, X_{2}, X_{3}, X_{1} X_{3}, X_{2} X_{3}, X_{1}^{2}, X_{2}^{2}$ and $X_{3}^{2}$ had $p$-values less than 0.05 and were significant.

The quadratic models for both bio-oil and biochar were found to have high values of "Adjusted R-Squared" (99.11, 99.61) \% and "Predicted R-Squared" $(96.65,98.31) \%$ showing that there was a deviation less than $5 \%$. The lack of fit test indicated that the quadratic models were found to have the minimum $F$ value and $p$-value thus having insignificant lack of fit. For the models $Y_{O}$ and $Y_{C}$ the "Lack of Fit F-value" of 1.266 and 1.87; denoted the Lack of Fit was not significant relative to the pure error and the $p$-value from this test suggests that there was 39.86 and $27.47 \%$
Table 6 ANOVA and F-test for Response Surface Quadratic Model

\begin{tabular}{|c|c|c|c|c|c|}
\hline \multicolumn{6}{|l|}{ Bio-oil } \\
\hline Source & $\begin{array}{l}\text { Sum of } \\
\text { squares }\end{array}$ & df & $\begin{array}{l}\text { Mean } \\
\text { square }\end{array}$ & $F$-value & $\begin{array}{l}p \text {-value } \\
\text { Prob }>\text { F }\end{array}$ \\
\hline Model & 8.85 & 9 & 0.98 & 199.29 & $<0.0001$ \\
\hline$X_{1}$ & 1.19 & 1 & 1.19 & 241.85 & $<0.0001$ \\
\hline$X_{2}$ & 0.33 & 1 & 0.33 & 66.47 & $<0.0001$ \\
\hline$X_{3}$ & 0.028 & 1 & 0.028 & 5.60 & 0.0499 \\
\hline$X_{1} X_{2}$ & 0.0006 & 1 & 0.0006 & 0.13 & 0.7324 \\
\hline$X_{1} X_{3}$ & 0.23 & 1 & 0.23 & 46.69 & 0.0002 \\
\hline$X_{2} X_{3}$ & 0.031 & 1 & 0.031 & 6.21 & 0.0415 \\
\hline$X_{1}^{2}$ & 2.33 & 1 & 2.33 & 472.91 & $<0.0001$ \\
\hline$X_{2}^{2}$ & 2.16 & 1 & 2.16 & 438.62 & $<0.0001$ \\
\hline$X_{3}^{2}$ & 1.80 & 1 & 1.80 & 365.48 & $<0.0001$ \\
\hline Residual & 0.035 & 7 & 0.0049 & & \\
\hline Lack of fit & 0.017 & 3 & 0.0056 & 1.266 & 0.3986 \\
\hline Pure error & 0.018 & 4 & 0.0044 & & \\
\hline Cor total & 8.89 & 16 & & & \\
\hline \multicolumn{6}{|l|}{ Biochar } \\
\hline Source & $\begin{array}{l}\text { Sum of } \\
\text { squares }\end{array}$ & $\mathrm{df}$ & $\begin{array}{l}\text { Mean } \\
\text { square }\end{array}$ & $F$-value & $\begin{array}{l}p \text {-value } \\
\text { Prob }>\text { F }\end{array}$ \\
\hline Model & 636.21 & 9 & 70.69 & 459.03 & $<0.0001$ \\
\hline$X_{1}$ & 521.65 & 1 & 521.65 & 3387.3 & $<0.0001$ \\
\hline$X_{2}$ & 109.52 & 1 & 109.52 & 711.17 & $<0.0001$ \\
\hline$X_{3}$ & 0.50 & 1 & 0.50 & 3.25 & 0.1146 \\
\hline$X_{1} X_{2}$ & 1.56 & 1 & 1.56 & 10.15 & 0.0154 \\
\hline$X_{1} X_{3}$ & 0.063 & 1 & 0.063 & 0.41 & 0.5444 \\
\hline$X_{2} X_{3}$ & 0.0025 & 1 & 0.0025 & 0.016 & 0.9022 \\
\hline$X_{1}^{2}$ & 1.38 & 1 & 1.38 & 8.96 & 0.0201 \\
\hline$X_{2}^{2}$ & 0.0032 & 1 & 0.0032 & 0.021 & 0.8897 \\
\hline$X_{3}^{2}$ & 1.38 & 1 & 1.38 & 8.96 & 0.0201 \\
\hline Residual & 1.08 & 7 & 0.15 & & \\
\hline Lack of fit & 0.63 & 3 & 0.21 & 1.87 & 0.2747 \\
\hline Pure error & 0.45 & 4 & 0.11 & & \\
\hline Cor total & 637.29 & 16 & & & \\
\hline
\end{tabular}

chance of insignificance, which is a large value might be due to noise. The non-significant lack of fit was good and the models were found to be fit [38]. A high coefficient of determination $\left(R^{2}\right) 99.61$ and $99.83 \%$ ensured a satisfactory adjustment of the quadratic models to the experimental data and justifies a high correlation between the observed $\left(Y_{e x p}\right)$ and the predicted values $\left(Y_{p r e}\right)$.

\subsection{Effect of process parameters on subcritical water extraction of bio-oil from Prosopis juliflora biomass}

The Subcritical water extraction of bio-oil and biochar production from Prosopis juliflora biomass was performed for different temperatures, reaction time and biomass to 
water loading to determine the optimum conditions. RSM and Contour plots were used to represent the effect of process parameters on this thermochemical conversion Fig. 4 and Fig. 5 exhibit the influence of temperature $\left(X_{1}\right)$, reaction time $\left(X_{2}\right)$ and biomass to water loading $\left(X_{3}\right)$ on bio-oil yield and biochar yield, where the significance of interactive variables was given in terms of response surface plots. a)

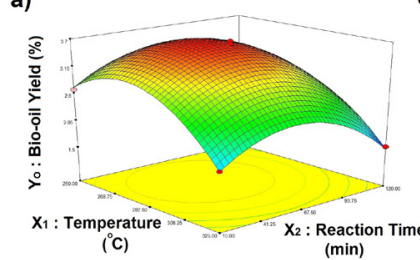

b)

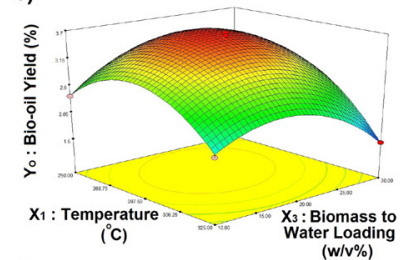

c)

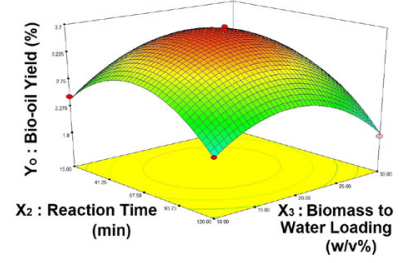

d)

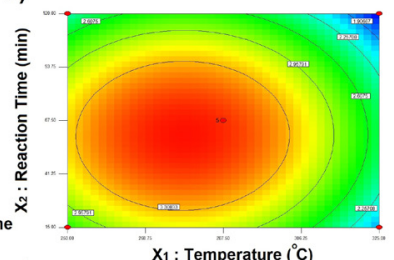

e)

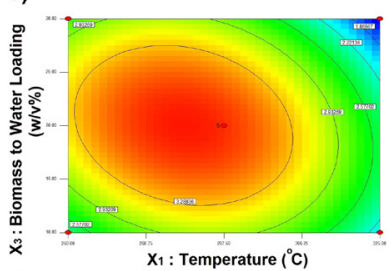

f)

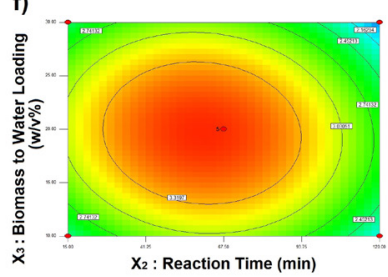

Fig. 4 a); b); c) 3D Response surface plots d); e); f) Contour plots showing the effects of variables on bio-oil yield a)

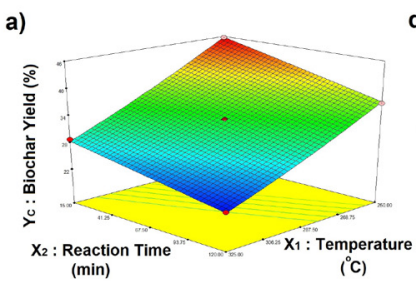

b)

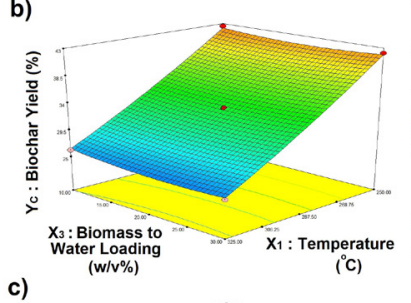

c)
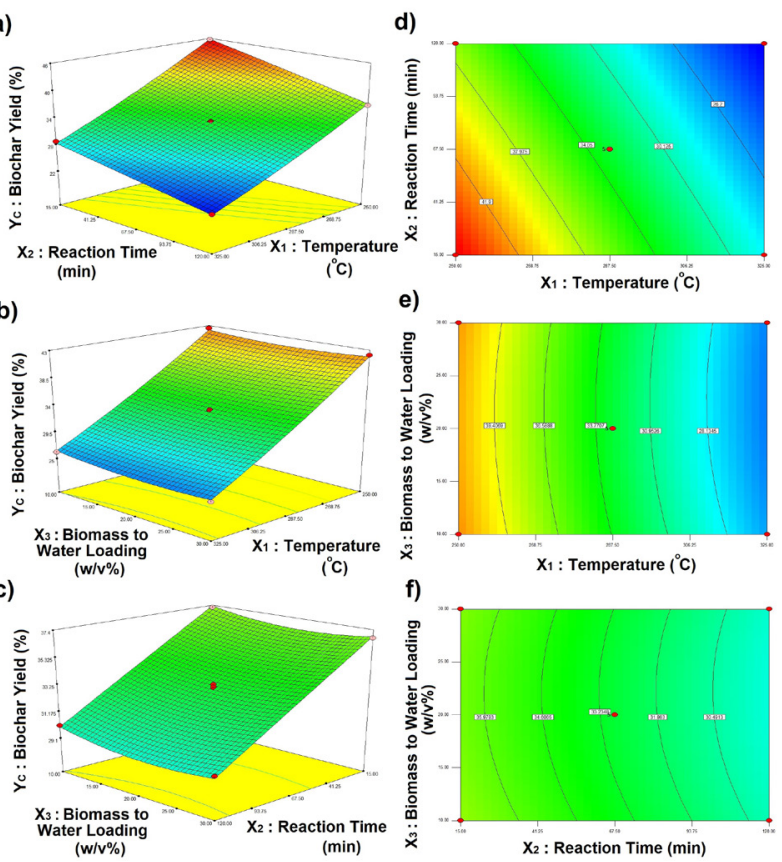

e)

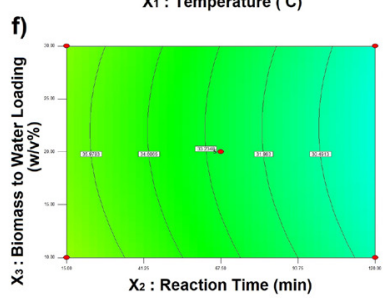

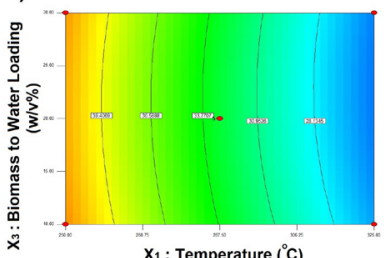

Fig. 5 a); b); c) 3D response surface plots d); e); f) Contour plots showing the effects of variables on biochar yield
The variables such as temperature, reaction time and biomass to water loading were found to significantly affect the bio-oil yield $\left(Y_{O}\right)$ with $p<0.05$ individually. The interactive effect of two interactive variables $X_{1} X_{3}$ and $X_{2} X_{3}$ showed a positive effect, while $X_{1} X_{2}$ showed a negative effect on $Y_{O}$ with the significance of $p<0.05$. In case of biochar yield $\left(Y_{C}\right)$ interactive effect was observed between temperature and reaction time i.e $X_{1} X_{2}$ with the significance of $p<0.05$.

It was observed from Figs. 4 (a) and (d) that the maximum bio-oil yields were between the temperature (approximately 260-300 ${ }^{\circ} \mathrm{C}$ ) and reaction time (30-93.75 $\mathrm{min}$ ), both the variables exhibiting quadratic effect. But beyond 300 to $325^{\circ} \mathrm{C}$, the bio-oil yield progressively decreases to a minimum of $1.52 \%$ because of bio-oil vaporization at these temperature ranges. Thus it is clear that high temperatures favor the radical formation that occurs generally in sub-critical water while the lower temperature induces the ionic reactions [39]. ANOVA results, Figs. 4 (b) and (e) show that the process parameters temperature and biomass to water loading were highly correlated and had a quadratic effect with a $p$-value $<0.05$. The plots in Figs. 4 (c) and (f) demonstrates a higher yield of bio-oil between the reaction time 30 and $93.75 \mathrm{~min}$. This is because the subcritical water extraction process needs sufficient time at the least about 15 to $20 \mathrm{~min}$ for the reaction initiation and propagation till the biomass is entirely converted to its products. Beyond $93.75 \mathrm{~min}$ there was a decrease in bio-oil yield, due to the further conversion of bio-oil to gaseous compounds. When biomass to water loading was increased beyond $20 \% \mathrm{w} / \mathrm{v}$ there was a decrease in the overall yield of bio-oil. Similar results were reported by Tungal and Shende [40] on hydrothermal liquefaction of pine sawdust, where the biooil yield increased with an increase in biomass to solvent ratio at $250{ }^{\circ} \mathrm{C}$ with a catalyst loading of $5 \mathrm{wt} \% \mathrm{Ni}\left(\mathrm{NO}_{3}\right)_{2}$, and 120 min reaction time; while no significant increase in the bio-oil yield was observed when the biomass to solvent ratio was increased further from 1:30 to 1:75 [40].

It is observed from Fig. 5 (a) and (d) that there is a progressive decrease in the biochar yield as the temperature and reaction time increases. Similar to the results obtained from the Table 6; Figs. 5 (b), (e) and (c), (f) confirms there is no interactive effect between temperature and biomass to water loading or reaction time and biomass to water loading.

\subsection{Selection of optimum conditions}

RSM optimization study for the subcritical water extraction of bio-oil from Prosopis juliflora biomass was performed to obtain maximum bio-oil yield. The process 
optimization of parameters: temperature $\left(X_{1}\right)$, reaction time $\left(X_{2}\right)$ and biomass to water loading $\left(X_{3}\right)$ were done by solving the response Eq. (8). The criteria between 0 (completely undesirable response) and 1 (fully desirable response) was fixed to maximize the bio-oil yield along the boundaries of BBD design. The lower limit in the response was 1.52 and the upper limit was 3.69, where numerical optimization was performed giving importance of "+++" to obtain 30 number of optimization cycles. The optimization resulted in $98.4 \%$ desirability at temperature $277.62{ }^{\circ} \mathrm{C}$, reaction time $59.98 \mathrm{~min}$ and biomass to water loading $20.13 \% \mathrm{w} / \mathrm{v}$ with a maximum bio-oil yield of $3.66 \%(33.19 \mathrm{mg} / \mathrm{g}$ of Prosopis juliflora biomass). The combined effect of the parameters on maximization of bio-oil yield and minimization of biochar yield was performed using numerical optimization and resulted with desirability of $75.9 \%$ at temperature $300.14{ }^{\circ} \mathrm{C}$, reaction time $75.12 \mathrm{~min}$ and biomass to water loading $19.19 \% \mathrm{w} / \mathrm{v}$ with a maximum bio-oil yield of $3.34 \%$ and minimum biochar yield of $29.74 \%$.

\subsection{GC-MS analysis of optimized subcritical bio-oil extract}

The experiment was repeated thrice for the optimized process parameters and the resulted bio-oil obtained through subcritical water extraction was characterized using a GC-MS analyzer. Fig. 6 shows the GC-MS Spectrum results for bio-oil at optimum condition and the constituents present in the bio-oil sample were as given in Table 7. The mean standard deviation of bio-oil yield for the three runs during optimized condition was found to be $3.65 \pm 0.048 \%$ which is in accordance with the predicted value. Thus the subcritical water extraction resulted in a mixture of long chain alkanes, ketones, carboxylic acids, amines and various phenolic fine chemicals like Guaiacol and Syringol.

\section{Conclusions}

The subcritical water extraction of bio-oil from Prosopis juliflora lignocellulosic biomass was performed
Table 7 GC-MS optimized bio-oil sample

\begin{tabular}{|c|c|c|c|c|}
\hline Rt Time & Area \% & $\begin{array}{l}\text { Mol. } \\
\text { Formula }\end{array}$ & $\begin{array}{l}\text { Mol. Wt. } \\
(\mathrm{g} / \mathrm{mol})\end{array}$ & IUPAC Name \\
\hline 4.469 & 2.7 & $\mathrm{C}_{4} \mathrm{H}_{8} \mathrm{O}_{3}$ & 104.10 & $\begin{array}{l}\text { Butanoic acid, } \\
\text { 4-hydroxy- }\end{array}$ \\
\hline 5.434 & 16.54 & $\mathrm{C}_{6} \mathrm{H}_{5} \mathrm{NH}_{2}$ & 93.13 & Aniline \\
\hline 6.741 & 30.63 & $\mathrm{C}_{9} \mathrm{H}_{20} \mathrm{O}_{3}$ & 176.25 & $\begin{array}{l}\text { Propane, } \\
\text { 1,1,3-triethoxy- }\end{array}$ \\
\hline 7.064 & 6.1 & $\mathrm{C}_{7} \mathrm{H}_{8} \mathrm{O}_{2}$ & 124.14 & Phenol, 2-methoxy- \\
\hline 7.302 & 5.43 & $\mathrm{C}_{14} \mathrm{H}_{30}$ & 198.39 & Tetradecane \\
\hline 9.436 & 3.34 & $\mathrm{C}_{14} \mathrm{H}_{30}$ & 198.39 & 2,3-Dimethyldodecane \\
\hline 9.599 & 2.64 & $\mathrm{C}_{21} \mathrm{H}_{44}$ & 296.60 & Eicosane, 10-methyl- \\
\hline 9.758 & 1.77 & $\mathrm{C}_{20} \mathrm{H}_{42}$ & 282.50 & $\begin{array}{l}\text { Hexadecane, } \\
\text { 2,6,10,14-tetramethyl- }\end{array}$ \\
\hline 10.399 & 5.29 & $\mathrm{C}_{14} \mathrm{H}_{30}$ & 198.39 & Tetradecane \\
\hline 10.503 & 7.49 & $\mathrm{C}_{14} \mathrm{H}_{30}$ & 198.39 & Tetradecane \\
\hline 10.841 & 5.67 & $\mathrm{C}_{8} \mathrm{H}_{10} \mathrm{O}_{3}$ & 154.16 & Phenol, 2,6-dimethoxy- \\
\hline 11.249 & 2.34 & $\mathrm{C}_{15} \mathrm{H}_{32}$ & 212.42 & Pentadecane \\
\hline 11.408 & 7.51 & $\mathrm{C}_{14} \mathrm{H}_{30}$ & 198.39 & Tetradecane \\
\hline 13.19 & 2.55 & $\mathrm{C}_{14} \mathrm{H}_{26} \mathrm{O}$ & 210.35 & $\begin{array}{l}\text { Propan-2-one, } \\
\text { 1-(4-isopropoxy-3- } \\
\text { methoxyphenyl)- }\end{array}$ \\
\hline
\end{tabular}

successfully by varying the process parameters such as temperature, reaction time and biomass to water loading. In this study, Box-Behnken Design of the statistical approach was applied effectively in finding the optimal process parameters for subcritical water extraction and the results indicated that the process conditions had a significant effect on the bio-oil yield. The 3D response surface plots and contour plots were employed to estimate the influence and interactive effects of process parameters on the response. The second-order polynomial models $Y_{O}$ and $Y_{C}$ were derived for predicting the bio-oil and biochar yield for the subcritical water extraction process. The ANOVA results indicated a high coefficient of determination $\left(R^{2}\right)$ of 0.9961 and 0.9983 ensuring a satisfactory fit of the predicted model with the experimental data. The process conditions for subcritical water extraction were found to be optimum at temperature $277.62{ }^{\circ} \mathrm{C}$, reaction time $59.98 \mathrm{~min}$ and

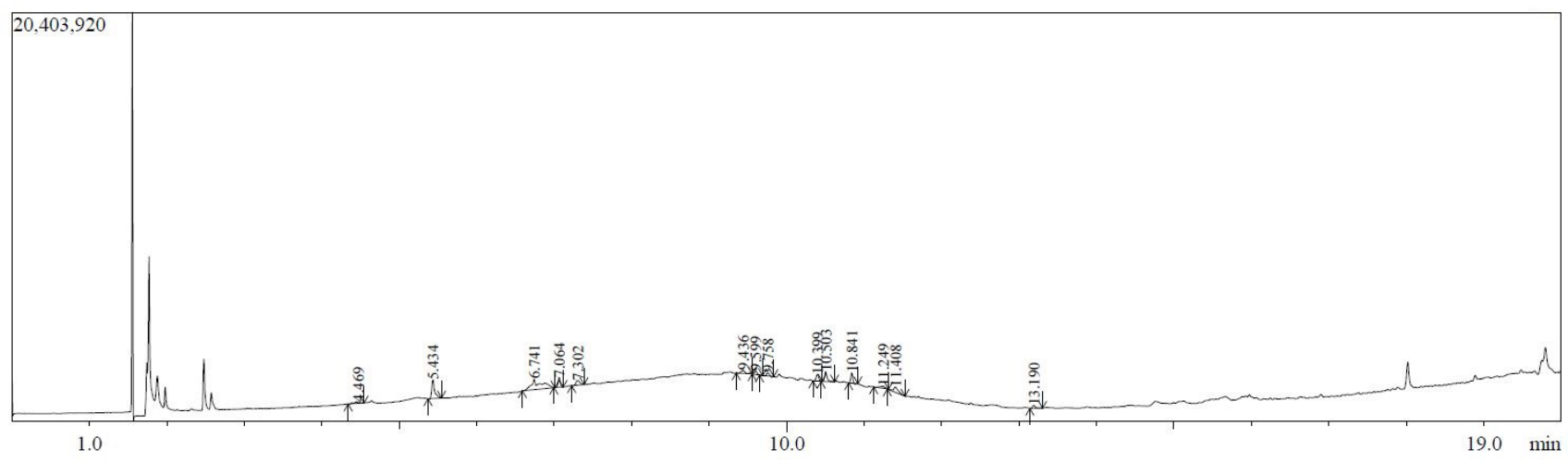

Fig. 6 - GC-MS Spectrum for bio-oil at optimum condition 
biomass to water loading $20.13 \% \mathrm{w} / \mathrm{v}$ that resulted in the maximum bio-oil yield of $3.65 \%$ (33.19 mg/g of biomass). These predicted process conditions agreed closely with the experimental values of bio-oil yield \% agreed closely and the models generated were found to be adequate.

\section{Acknowledgement}

The authors express their gratitude to Centre of Excellence in Advanced Materials and Green Technologies, Amrita Vishwa Vidyapeetham University, Coimbatore funded by Ministry of Human Resource and Development (MHRD)

\section{References}

[1] European and Mediterranean Plant Protection Organization "Prosopis juliflora (Sw.) DC.", Bulletin OEPP EPPO Bulletin, 49(2), pp. 290-297, 2019.

https://doi.org/10.1111/epp.12531

[2] Patel, R. S., Patel, H. R., Kanjariya, K. V. "Observation on Leguminous Plants with Their Taxonomy and Medicinally Uses of Ahmedabad Zoo, Gujarat, India", International Journal of Scientific Research in Science and Technology, 4(5), pp. 590-602, 2018. [online] Available at: http://ijsrst.com/ paper/2807.pdf_[Accessed: 22 October 2019]

[3] Gupta, R., Sharma, K. K., Kuhad, R. C. "Separate hydrolysis and fermentation (SHF) of Prosopis juliflora, a woody substrate, for the production of cellulosic ethanol by Saccharomyces cerevisiae and Pichia stipitis-NCIM 3498", Bioresource Technology, 100(3), pp. 1214-1220, 2009 https://doi.org/10.1016/j.biortech.2008.08.033

[4] Oduor, N. M., Githiomi, J. K. "Fuel-wood energy properties of Prosopis juliflora and Prosopis pallida grown in Baringo District, Kenya.", African Journal of Agricultural Research, 8(21), pp. 2476-2481, 2013. [online] Available at: https://www.cabi.org/ ISC/abstract/20133238370 [Accessed: 22 October 2019]

[5] Vidal Gomes, A., Bolzón de Muñiz, G. I. "Chapter 3: Botany Wood Structure and Ultrastructure of Prosopis caldenia, P. chilensis and P. juliflora and Influence of Ecological Factors", In: II International Conference on Prosopis - The Current State of Knowledge on Prosopis juliflora, Recife, Brazil, 1988, Article Number: 3. [online] Available at: http://www.fao.org/3/AD317E/ AD317E08.htm\#ch3.3 [Accessed: 24 October 2019]

[6] Kolappan, B. "Seemai karuvelam, a saviour-turned-villain whose tentacles spread far and wide", The Hindu, [online] 28 February 2017. [online] Available at: https://www.thehindu.com/news/national/ tamil-nadu/a-saviourturnedvillain-whose-tentacles-spread-far-andwide/article17379253.ece [Accessed: 22 October 2019]

[7] Tamiru, G. "Invasive Alien Weed Species Distribution, Impacts on Agriculture, Challenge and Reaction in Ethiopia: A Review", Biology Agriculture Healthcare, 7(7), pp. 136-146, 2017. [online] Available at: https://www.iiste.org/Journals/index.php/JBAH/article/view/36483 [Accessed: 22 October 2019] for the characterization, Department of Chemical Engineering, Kongu Engineering College, Perundurai, Erode and Department of Agroforestry, Forest College and Research Institute, Mettupalayam for providing infrastructure facilities and support to carry out the above research. The authors also express their gratitude to undergraduate students Pushparaj Nallusamy, Saravanan Padmanathan and Vidhya Sangeetha Kumarasamy of 2014 to 2019 batch from the Department of Chemical Engineering, Kongu Engineering College, Perundurai, Erode.

[8] Boy, G., Witt, A. "Invasive alien plants and their management in Africa: how a multi-country "War on Weeds" project is helping an infested continent to stem the colonising onslaught of invasive species", UNEP/GEF Removing Barriers to Invasive Plant Management Project Coordination Unit, Nairobi, Kenya, 2013. [online] Available at: https://www.iucn.org/content/invasive-alienplants-and-their-management-africa-how-a-multi-country-warweeds-project-helping-infested-continent-stem-colonising-onslaught-invasive-species [Accessed: 24 October 2019]

[9] Australian Weed Management "Mesquite - Prosopis species", Weed Management Guide, pp. 1-8, 2003. [online] Available at: https://www.environment.gov.au/biodiversity/invasive/weeds/ publications/guidelines/wons/pubs/prosopis.pdf [Accessed: 22 October 2019]

[10] Phillips, W. S. "Depth of Roots in Soil", Ecology, 44(2), pp. 424-424, 1963.

https://doi.org/10.2307/1932198

[11] William, K., Jafri, L. "Mesquite (Prosopis juliflora): Livestock Grazing, Its Toxicity and Management", Journal of Bioresource Management, 2(2), pp. 49-58, 2015. https://doi.org/10.35691/JBM.5102.0021

[12] Kumar, S., Mathur, M. "Impact of invasion by Prosopis juliflora on plant communities in arid grazing lands", Tropical Ecology, 55(1), pp. 33-46, 2014. [online] Available at: http://www.tropecol.com/pdf/open/PDF_55_1/03-Kumar\%20\&\%20Mathur.pdf [Accessed: 20 October 2019]

[13] Dzikiti, S., Schachtschneider, K., Naiken, V., Gush, M., Moses, G., Le Maitre, D. C. "Water relations and the effects of clearing invasive Prosopis trees on groundwater in an arid environment in the Northern Cape, South Africa", Journal of Arid Environment, 90, pp. 103-113, 2013. https://doi.org/10.1016/j.jaridenv.2012.10.015

[14] Sameera, V., Sameera, C., Ravi Teja, Y. "Current Strategies Involved in Biofuel Production from Plants and Algae", Journal of Microbial \& Biochemical Technology, R1(002), pp. 1-10, 2011. https://doi.org/10.4172/1948-5948.R1-002

[15] Đurić, S. N., Kaluđerović, Ž. Lj., Kosanić, T. R., Ćeranić, M. B., Milotić, M. M., Brankov, S. D. "Experimental Investigation of Pyrolysis Process of Agricultural Biomass Mixture", Periodica Polytechnica Chemical Engineering, 58(2), pp. 141-147, 2014. https://doi.org/10.3311/PPch.7199 
[16] Chen, M. J., Li, R. M., Zhang, X. Q., Feng, J., Feng, J., Liu, C. F., Shi, Q. S. "Homogeneous Transesterification of Sugar Cane Bagasse toward Sustainable Plastics", ACS Sustainable Chemistry and Engineering, 5(1), pp. 360-366, 2017. https://doi.org/10.1021/acssuschemeng.6b01735

[17] Gollakota, A. R. K., Kishore, N., Gu, S. "A review on hydrothermal liquefaction of biomass", Renewable and Sustainable Energy Reviews, 81, pp. 1378-1392, 2018. https://doi.org/10.1016/j.rser.2017.05.178

[18] Elliott, D. C., Biller, P., Ross, A. B., Schmidt, A. J., Jones, S. B. "Hydrothermal liquefaction of biomass: Developments from batch to continuous process", Bioresource Technology, 178, pp. 147-156, 2015. https://doi.org/10.1016/j.biortech.2014.09.132

[19] Elliott, D. C. "19 - Production of biofuels via bio-oil upgrading and refining", In: Luque, R., Lin, C. S. K., Wilson, K., Clark, J. (eds.) Handbook of Biofuels Production: Processes and Technologies, Woodhead Publishing, Amsterdam, Netherlands, 2016, pp. 595-613. https://doi.org/10.1016/B978-0-08-100455-5.00019-9

[20] Chitra Devi, V., Mothil, S., Sathish Raam, R., Senthilkumar, K. "Thermochemical Conversion and Valorization of Woody Lignocellulosic Biomass in Hydrothermal Media", In: Praveen Kumar, R., Bharathiraja, B., Kataki, R., Moholkar, V. S. (eds.) Biomass Valorization to Bioenergy: Energy, Environment, and Sustainability, Springer, Singapore, Singapore, 2020, pp. 45-63. https://doi.org/10.1007/978-981-15-0410-5_4

[21] Kamaleswaran, K., Harinath, P., Prabhakaran, S., Rajakumaran, V., Damini, M., Kirubakaran, V. "Comparative Analysis of Combustion Vs Auto-gasification of Prosopis Juliflora Sticks for Rural Household Application", Procedia Environmental Sciences, 35, pp. 860-868, 2016.

https://doi.org/10.1016/j.proenv.2016.07.103

[22] Natarajan, P., Suriapparao, D. V., Vinu, R. "Microwave torrefaction of Prosopis juliflora: Experimental and modeling study", Fuel Processing Technology, 172, pp. 86-96, 2018. https://doi.org/10.1016/j.fuproc.2017.12.007

[23] Suriapparao, D. V., Pradeep, N., Vinu, R. "Bio-Oil Production from Prosopis juliflora via Microwave Pyrolysis", Energy \& Fuels, 29(4), pp. 2571-2581, 2015.

https://doi.org/10.1021/acs.energyfuels.5b00357

[24] Kumar, R., Chandrashekar, N. "Study on fuelwood and carbonization characteristics of Prosopis juliflora", Journal of Indian Academy Wood Science, 13(2), pp. 101-107, 2016.

https://doi.org/10.1007/s13196-016-0171-9

[25] Mythili, R., Subramanian, P., Uma, D. "Physicochemical properties of the bio-oil from Prosopis juliflora in fluidized-bed reactor", Energy Sources, Part A: Recovery, Utilization, and Environmental Effects, 39(8), pp. 843-849, 2017. https://doi.org/10.1080/15567036.2016.1270374

[26] Arun, J., Gopinath, K. P., Sundar Rajan, P. S., Joselyn Monica, M., Felix, V. "Co-liquefaction of Prosopis juliflora with polyolefin waste for production of high grade liquid hydrocarbons", Bioresource Technology, 274, pp. 296-301, 2019.

https://doi.org/10.1016/j.biortech.2018.11.102
[27] Sridhar, D., Madhu, G. M. "Drying Kinetics and Mathematical Modeling of Casuarina Equisetifolia Wood Chips at Various Temperatures", Periodica Polytechnica Chemical Engineering, 59(4), pp. 288-295, 2015.

https://doi.org/10.3311/PPch.7855

[28] TAPPI (Technical Association of Pulp and Paper Industry) "T 211 om-02: Ash in wood, pulp, paper and paperboard: combustion at $525^{\circ} \mathrm{C}$, TAPPI (Technical Association of Pulp and Paper Industry), Peachtree Corners, GA, USA, 2002. [online] Available at: https:// www.tappi.org/content/sarg/t211.pdf [Accessed: 24 October 2019]

[29] TAPPI (Technical Association of Pulp and Paper Industry) "T 550 om-08: Determination of equilibrium moisture in pulp, paper and paperboard for chemical analysis", Peachtree Corners, GA, USA, 2013. [online] Available at: https://www.tappi.org/content/tag/ sarg/t550.pdf [Accessed: 24 October 2019]

[30] Sheng, C., Azevedo, J. L. T. "Estimating the higher heating value of biomass fuels from basic analysis data", Biomass and Bioenergy, 28(5), pp. 499-507, 2005.

https://doi.org/10.1016/j.biombioe.2004.11.008

[31] Thakur, A., Panesar, P. S., Saini, M. S. "Parametric Optimization of Lactic Acid Production by Immobilized Lactobacillus casei Using Box-Behnken Design", Periodica Polytechnica Chemical Engineering, 62(3), pp. 274-285, 2018.

https://doi.org/10.3311/PPch.11403

[32] Manikandan Periasamy, S., Baskar, R. "Assessment of the Influence of Graphene Nanoparticles on Thermal Conductivity of Graphene/ Water Nanofluids Using Factorial Design of Experiments", Periodica Polytechnica Chemical Engineering, 62(3), pp. 317-322, 2018. https://doi.org/10.3311/PPch.11676

[33] Senrayan, J., Venkatachalam, S. "Optimization of ultrasound-assisted solvent extraction (UASE) based on oil yield, antioxidant activity and evaluation of fatty acid composition and thermal stability of Coriandrum sativum L. seed oil", Food Science and Biotechnology, 28(2), pp. 377-386, 2019. https://doi.org/10.1007/s10068-018-0467-1

[34] Venkatachalam, C. D., Sengottian, M., Kandasamy, S., Balakrishnan, K. "Biogenic synthesis of PdNCs embedded $\alpha$-Fe2O3 microspheres using Myrtus cumini L. leaf extract and a Box-Behnken optimization of its Fenton-like catalytic activity", Global NEST Journal, 21(3), pp. 410-421, 2019. https://doi.org/10.30955/gnj.003133

[35] Thirugnanasambandham, K., Sivakumar, V. "Influence of process conditions on the physicochemical properties of pomegranate juice in spray drying process: Modelling and optimization", Journal of the Saudi Society of Agricultural Sciences, 16(4), pp. 358-366, 2017. https://doi.org/10.1016/j.jssas.2015.11.005

[36] Kapur, M., Gupta, R., Mondal, M. K. "Parametric optimization of $\mathrm{Cu}$ (II) and Ni (II) adsorption onto coal dust and magnetized sawdust using box-behnken design of experiments", Environmental Progress \& Sustainable Energy, 35(6), pp. 1597-1604, 2016. https://doi.org/10.1002/ep.12393

[37] Greenland, S., Senn, S. J., Rothman, K. J., Carlin, J. B., Poole, C., Goodman, S. N., Altman, D. G. "Statistical tests, $P$ values, confidence intervals, and power: a guide to misinterpretations", European Journal of Epidemiology, 31(4), pp. 337-350, 2016. https://doi.org/10.1007/s10654-016-0149-3 
[38] Nasiri Azad, F., Ghaedi, M., Dashtian, K., Montazerozohori, M., Hajati, S., Alipanahpour, E. "Preparation and characterization of MWCNTs functionalized by $N$-(3-nitrobenzylidene)- $N$ 'trimethoxysilylpropyl-ethane-1,2-diamine for the removal of aluminum(III) ions via complexation with eriochrome cyanine R: Spectrophotometric detection and optimization", RSC Advances, 5(75), pp. 61060-61069, 2015.

https://doi.org/10.1039/C5RA08746E

[39] Watanabe, M., Sato, T., Inomata, H., Smith Jr., R. L., Arai Jr., K., Kruse, A., Dinjus, E. "Chemical Reactions of $\mathrm{C}_{1}$ Compounds in Near-Critical and Supercritical Water", Chemical Reviews, 104(12), pp. 5803-5822, 2004.

https://doi.org/10.1021/cr020415y
[40] Tungal, R., Shende, R. V. "Hydrothermal liquefaction of pinewood (Pinus ponderosa) for $\mathrm{H}_{2}$, biocrude and bio-oil generation", Applied Energy, 134, pp. 401-412, 2014.

https://doi.org/10.1016/j.apenergy.2014.07.060 